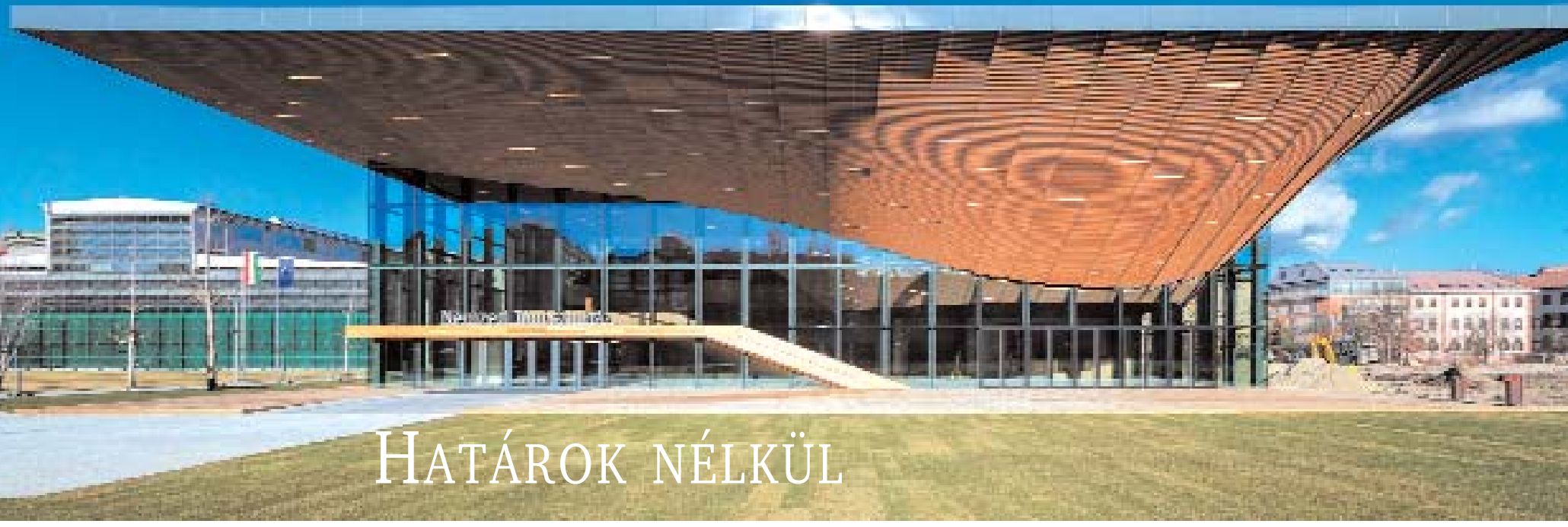

Föhomlokzat: faburkolatba csomagolt térplasztika

\title{
Nemzeti Táncszínház a Millenáris Parkban
}

Mechwart András, Zipernowsky Károly, Déri Miksa és Bláthy Ottó Titusz. Csupa olyan jeles férfiú, aki a budai Millenáris Park területén álló volt Ganz Villamossági Mưvekhez kötődik. Ganz Ábrahám örököseként Mechwart 1878-ban itt alapította meg a vállalat elektrotechnikai osztályát. Ezen a helyen látott napvilágot az első öngerjesztésű váltakozó áramú generátor és Zipernowskyék világszabadalma (1885), ami megoldotta a transzformátoron alapuló villamosenergia-elosztás és energiaátvitel kérdését. [1] A hely aurája felölel közel százötven évet és magában foglalja az Országút jelentős részét, amelynek határát keletről a Mechwart liget jelöli.

A Ganz budai telepének tudomány- és ipartörténeti jelentőségű transzformátorgyárát a második világháborúban lebombázták, majd 1947-ben az eredeti helyén egy új háromhajós csarnokot emeltek. A szintmegosztás nélküli, nagy belmagasságú bazilika tetőszerkezete alatt a szocialista korszakban is folyt a termelés. [2] A gyár területét 1990 után ötletszerüen hasznosították tíz éven át, végül magán- és állami érdekeltségek között osztották fel. Utóbbi sorsáról kormányhatározat döntött, és a millennium apropóján jelképesen a magyar tudomány és innováció parkjává szentelték fel. A megosztott beruházás produktuma azonban nem egy klasszikus ipari park lett, hanem sokféle kezdeményezés egyvelege, amelyen belül a kulturális kapacitás jelentősége nőtt meg. A Millenáris végérvényesen 2012-ben lépett erre az útra, amikor a Láthatatlan Kiállítás ide költözött.

A rendszerváltás utáni időszak bizonytalanságai közepette a transzformátorgyár épületét egy televíziós stúdiószínpad használta, bár sokáig nyitva állt még egy alternatív irány: a Ganz múvek egy része megmaradhatott volna a „munka templomának”, ahogy Berlinben a több mint száz éve múködő AEG turbinagyár. [3] Noha Peter Behrens premodern alkotása csodával határos módon túlélte a második világháborút, míg a Kis Rókus utcai csarnok nem, a genius loci itt is valamivel több figyelmet érdemelt volna a városatyáktól.

A Nemzeti Táncszínház megjelenése már a kulturális fórum melletti döntés következménye, jóllehet összekapcsolódik a budavári karmelita kolostor átalakításával, amelynek egykori temploma 1787-től Budapest első kőszínházának, 2001-2014 között pedig a Nemzeti Táncszínháznak adott otthont. A költöző intézmény a Millenáris Teátrumot váltja, amely a régi trafógyár szabadtéri színpaddal megtoldott együttesét (E jelú épület) foglalta el. Zoboki Gáborék (ZDA) terve egy komplexebb program részeként idővel a Millenáris lüktető szíve lesz.

A határozatlan térfalú, de zárt tömegekkel övezett park közepén a közelmúltban még egy mesterséges tó terült el. A tó ugyan eltunnt, de megváltozott a Millenáris üzenete is. A ritkán látogatott kuriózumok mellé beköltözött a közélet, amely nemcsak a helyszínt, de a Táncszínház entitását is újraértelmezi. A kommunikáció szempontjából ezért megnőtt a jelentősége a formatervezésnek. [4] Erre különösen érzékeny ez a kor, amelyben hozzászoktunk, hogy minden formához kulturális üzenetek társulnak, noha a terek és térrendszerek titkosabb világa is rendelkezik hasonlókkal. [5] Míg az előbbi általában közérthető, az utóbbi kódolásához és dekódolásához a szakma elitjéhez kell tartozni. A ZDA épülete finoman formatervezett, de összhatásában domináns előterével mindkét kritériumnak megfelel még akkor is, ha számításba vesszük, hogy az új narthex a meghosszabbított háromhajós bazilikának alig negyedét teszi ki, míg az épület hátsó kubatúrája jóformán érintetlen maradt.

A méretében tekintélyes és vizuálisan tökéletesen nyitott előtérre kevés hasonló példánk van. A meglévő épületet interpretáló, de azt formailag és programjában meghaladó kulturális fórum gondolata kisebb léptékben 
a veszprémi Hangvillánál (Anthony Gall, 2013) [6], nagyobb léptékben pedig a vásárcsarnokot rendezvényközponttal házasító újpesti piacnál (Bun Zoltán, 2018) is megvalósult, ám a funkciók vegyessége egyiknél sem teremtett olyan tiszta szituációt [7], mint a táncszínházi foyer. Utóbbiról az az érzésünk, mintha megtoldaná a fizikai teret, ami elméletileg lehetetlen, hacsak nem négydimenziós koordinátarendszert alkalmazunk. [8] Amilyen elvont ez a tapasztalat, épp olyan autonóm az épület. Élénk dinamizmusa magával ragadó, mégis letisztult. Nincs már benne semmi a Müpa előcsarnokának heterogén, kissé túlformált enteriőrjéből. [9] Az átlátha- nyezetbe, az Erzsébet térre! Itt a színház mellé a kávé, ott a kávé mellé egy színház jönne jól. [12]

A faburkolatba csomagolt térplasztika legattraktívabb eleme az előcsarnokot fedő hiperbolikus felület. A szemlélő itt már önkényességet neszel, de ismét csalatkozik: a redőző födém egy újabb lelátó vonalait követi, ezúttal alulról. Az emeleten a kamaraszínpad található, amelynek belseje a hagyományos szcenikai konfigurációkon túl olyan egységes tér hatását kelti, ahol a színpad-nézőtér között nincs éles határ, így a néző inkább résztvevője az előadásoknak. Ez a gondolat az egész terven következetesen vonul végig. Nemcsak az emeleten és az előcsar-

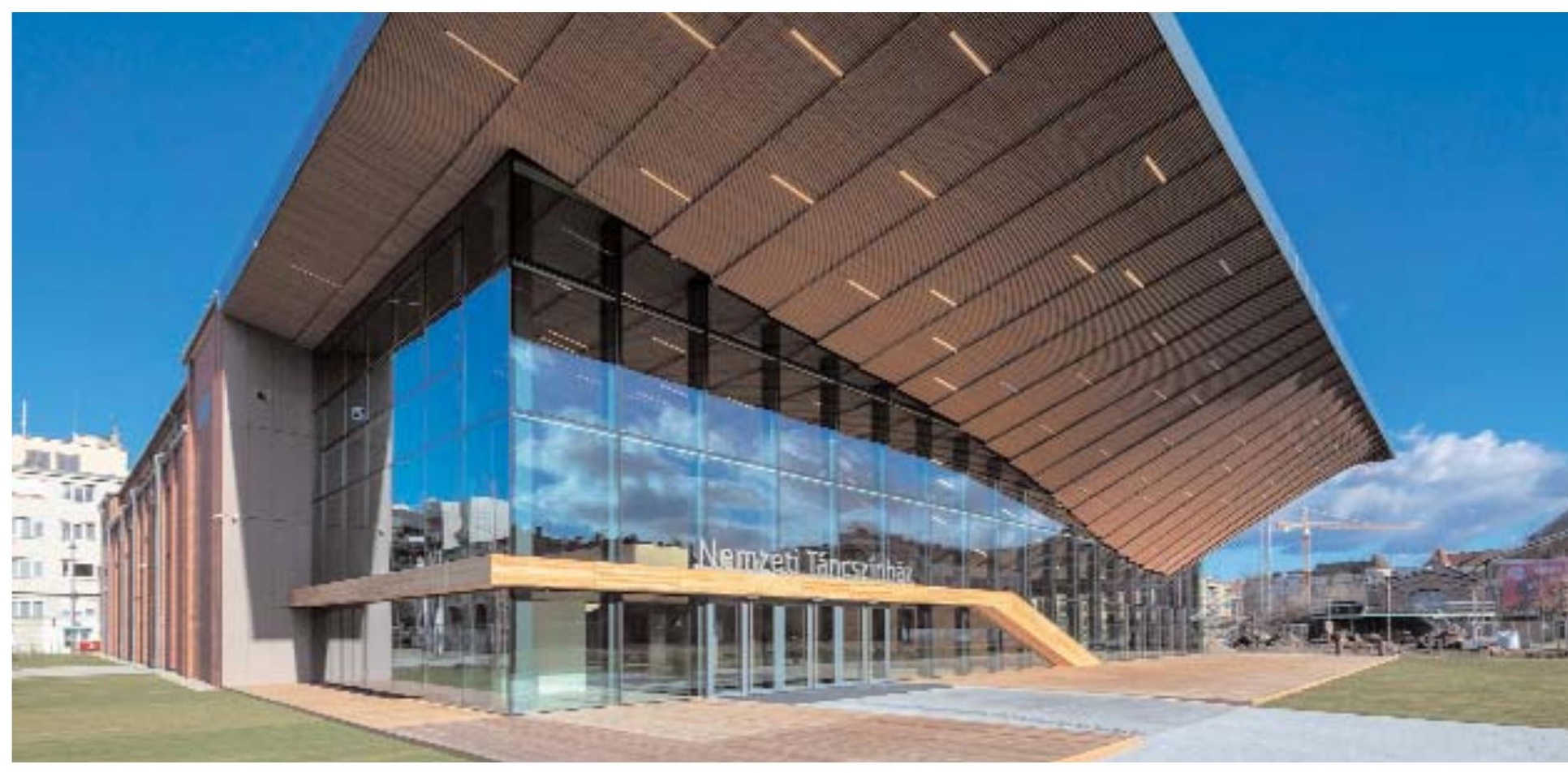

tó, már-már üres előcsarnok visszafogott anyaghasználata és lecsendesített részletei mellett jól érvényesül a vonal ereje. A folytonos vonalé, amely a tervező lendületes kézjegye.

Ahogy egykor Alvar Aaltónál a viipuri könyvtár (1927-1935) auditóriumának hullámvonalú mennyezetét, Zobokinál a széles, felfelé keskenyedő lépcsőt is indokolja a praktikum, hiszen az nemcsak egy barokkos, reprezentatív lépcső, hanem másodlagosan egy színházi lelátó is. Az előtér nem az üresség apoteózisa [10] (az építészetelmélet nyelvén: deformáció), hanem láthatatlan színpad, amely megtölthető a legkülönfélébb programokkal (információval). [11] E rejtett pódium a csarnok fénnyel átjárt, vetett árnyékokkal átszőtt alapterületével keveredik, ahogy összeolvad a fedett-nyitott terasszal is. Utóbbi nem is marad kitöltetlenül. Itt lennének azok a kávézóasztalok, amelyek - akárcsak a Müpánál - a városi kontextus illúziójának hiteles díszletei. Fordítsuk meg a gondolatot és helyezzük át egy elfeledett urbánus kör- nokban, hanem az előcsarnok és a nagyterem között, valamint magában a nagyteremben is felfedezhető. A régi és az új épületrész határán nyíló méretes kapuk a semperi háromosztatú színháztípusnak újabb belső határvonalát számolják fel. [13] Mi több, az eredeti elképzelések szerint itt egy teljesen eltűnő mobil falnak kellene állnia.
Metszet: az elöcsarnok mennyezete a kamaraszínpad nézőterének vonalát követi

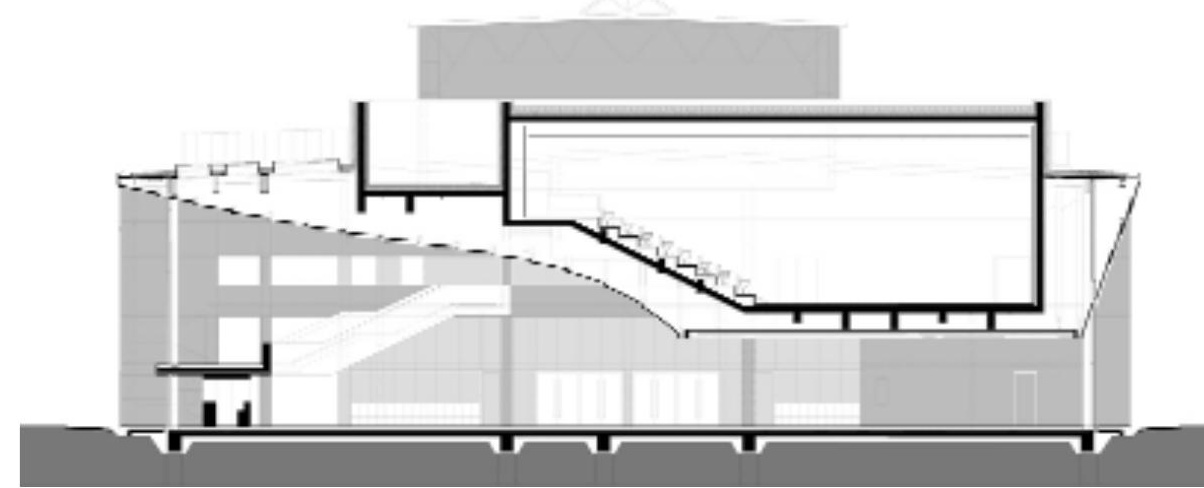




\section{Az elöcsarnok felfelé keskenyedő lépcsője egyben színházi lelátó}

\section{Irodalom / References}

[1] Berlász, Jenő: „A Ganz-gyár első félszázada 1845-1895", Tanulmányok Budapest Múltjából, Vol 12 (1957), pp 349-458.

[2] Koroknai, Ákos: A Ganz Müszer Művek története, Ganz Müszer Művek, Budapest 1975. [3] Fischer, Jan Otakar: „A Berlin Landmark Keeps on Keeping On", The New York Times (online), 2010-01-18, hozzáférhető: <https://www.nytimes.com/2010/01/19/arts/ 19iht-turbine.html> [utolsó belépés: 201902-02].

[4] Baudrillard, Jean: A tárgyak rendszere, Gondolat, Budapest, 1987.

[5] Lefebvre, Henri: „A tér termelése”, in Moravánszky Ákos - M Gyöngy Katalin (eds), A tér: Kritikai antológia, Terc, Budapest 2007, pp 220-225.

[6] Katona, Vilmos: „Idők jelei: Hangvilla Veszprémben", Régi-új Magyar Épitőmüvészet, No 1 (2014), pp 4-7.

[7] Wesselényi-Garay, Andor: „Nézőpontok között: Az újpesti új Vásárcsarnok és Kulturális Rendezvényközpont", Metszet, Vol 9, № 6 (2018), pp 10-17.

[8] Talata, István: „Négydimenziós konvex politóp ábrázolása GeoGebrával", Dimenziók Matematikai Közlemények, Vol 5 (2017), pp 11-18, DOl: <10.20312/dim.2017.02>. [9] Wesselényi-Garay, Andor: „Illusztratív építészet", Alaprajz, Vol 12, No 1 (2005), pp 12-17.

[10] Katona, Vilmos: „Az 'üresség tere': A pannonhalmi bazilika szentélye", Régi-új Magyar Épitőmüvészet, № 10 (2015), pp 22-24.

[11] Kipnis, Jeffrey: „Egy új épitészet felé”, in Kerékgyártó Béla (ed): A mérhető és a mérhetetlen: Épitészeti irások a huszadik századból (második kiadás), Typotex, Budapest 2004 pp 348-367.

A vonal ereje az elöcsarnokban
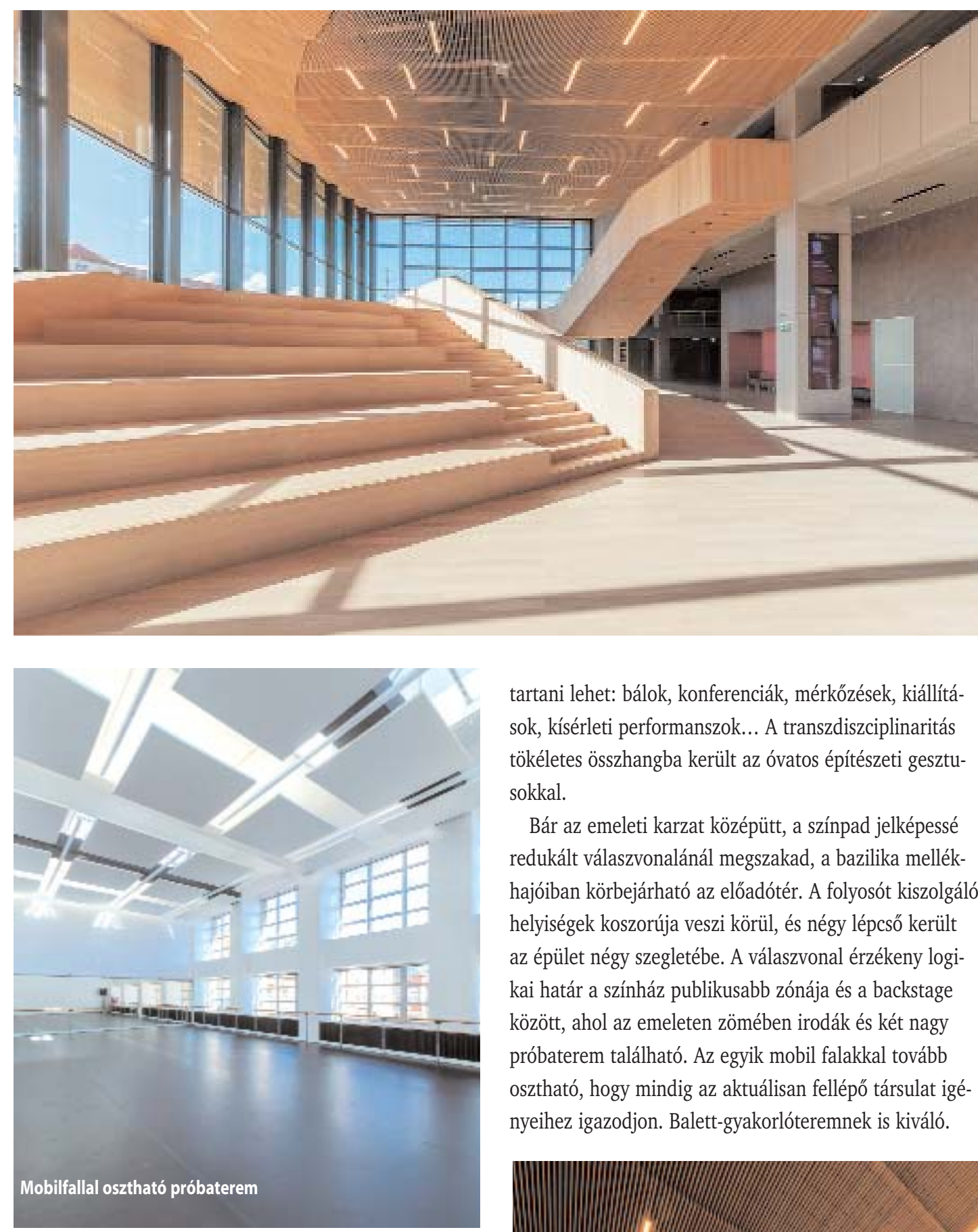

A nagyterem háromszáznyolcvannégy néző befogadására képes, de ez egy viszonylagos szám, ami csak hagyományos, frontális nézőtéri elrendezés mellett érvényes. A koncepció itt is az egy-tér ideája volt, amelyet két fontos érv indokol. A funkció oldaláról közelítve a maximális átrendezhetőség programja, a meglévő épület védelme szempontjából pedig az, hogy így az ipari múemlékhez nem kellett jelentős mértékben hozzányúlni. A földszinten még a színházi minimumnak gondolt színpadi emelvény is hiányzik, és a csarnok teljes területe fölött - beleértve az alkalmi nézőteret is - alacsony belmagasságú zsinórpadlás található. Talán még a megbízó sem vette lajstromba mindazoknak a rendezvényeknek a sorát, amelyeket egy ilyen térben a táncbemutatón kívül tartani lehet: bálok, konferenciák, mérkőzések, kiállítások, kísérleti performanszok... A transzdiszciplinaritás tökéletes összhangba került az óvatos építészeti gesztusokkal.

Bár az emeleti karzat középütt, a színpad jelképessé redukált válaszvonalánál megszakad, a bazilika mellékhajóiban körbejárható az előadótér. A folyosót kiszolgáló helyiségek koszorúja veszi körül, és négy lépcső került az épület négy szegletébe. A válaszvonal érzékeny logikai határ a színház publikusabb zónája és a backstage között, ahol az emeleten zömében irodák és két nagy nyeihez igazodjon. Balett-gyakorlóteremnek is kiváló.

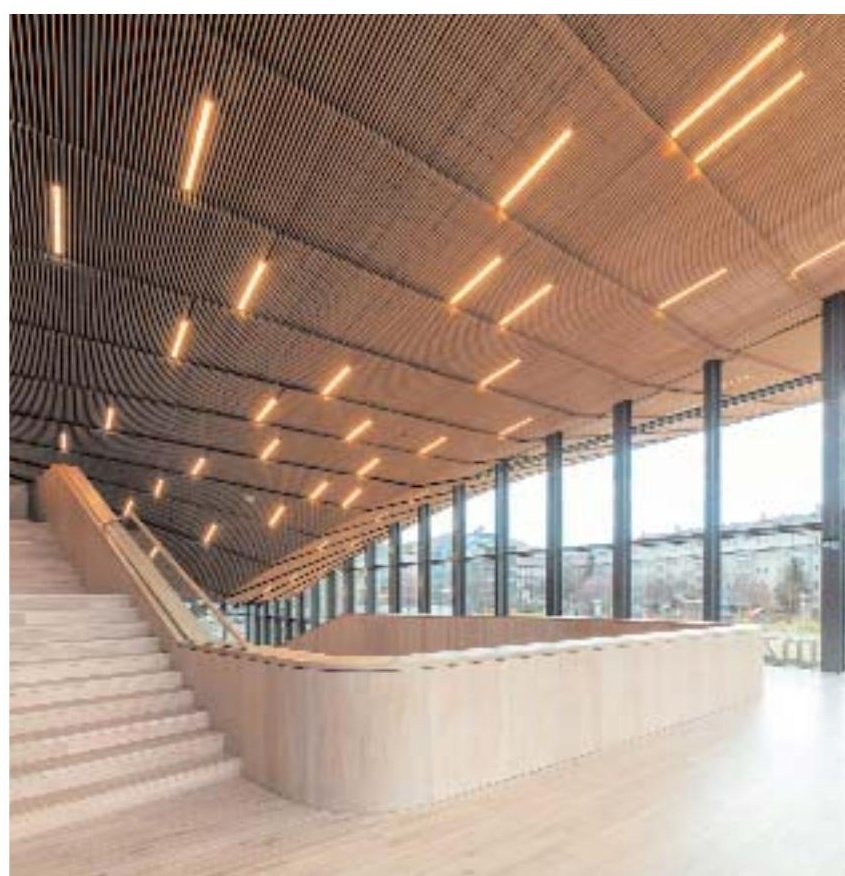
próbaterem található. Az egyik mobil falakkal tovább osztható, hogy mindig az aktuálisan fellépő társulat igé- 


\section{$\mathrm{A}$}

WESSELÉNYI-GARAY, Andor: SPACE AND BODY GAME Citation: Metszet, Vol 10, № 1 (2019), pp 18-25, DOI: 10.33268/Met.2019.1.1 TELEKOM HEADQUARTERS, BUDAPEST, HUNGARY

ARCHITECTS - TIBA ÉPÍTÉSZ STÚDIÓ

Office developments often take on the role of being works of art. This being a result of many factors, location on major urban arterial routes, occupancy levels, urban planning restrictions and market presence. Here the option of placing one vast body of office space on a corner site would not suffice. Three courtyards of differing in nature have been enclosed, one is semi-public, another is semiprivate and the third a private park. From these spaces the surrounding volume has been developed as a truncated, sectioned solid. Style is a lesser question as the project aims to demonstrate the occupants market presence as the leading company in its given sector. Providing not only workspace, also relaxation area, dining areas and a lifestyle pattern inherent to company values.

\section{LAMERS, Emiel: EAST MEETS WEST, WEST MEETS EAST}

\section{Citation: Metszet, Vol 10, № 1 (2019), pp 26-29, DOI: 10.33268/Met.2019.1.2}

Examining what happens when architects are commissioned to work away from home. Is this a result of client loyalty to an "in-house" architect, architectural celebrity, open competitions or market pressure. Often these projects result in a collaboration between architectural practices that can often generate a new set of ideas outside of the standard understanding of context, innovation and social exchange. It will be interesting to see what happens when east meets west at the next congress in Budapest.

\section{VAN BERKEL, Ben: CELEBRATION OF THE WORLD OF THEATRE Citation: Metszet, Vol 10, № 1 (2019), pp 30-33, DOI: 10.33268/Met.2019.1.3}

Locating three theatres, all of varied capacity and different in character, within one building seems to be a work of spatial choreography. This has been achieved by arranging the spaces around a central spine where all functions have been placed within a transparent stacked building, moving away from the traditional concept of theatres being closed black boxes, towards transparency and openness.

\section{KATONA, Vilmos: WITHOUT LIMITS}

\section{Citation: Metszet, Vol 10, No 1 (2019), pp 34-37, DOI: 10.33268/Met.2019.1.4}

NATIONAL DANCE THEATRE AT MILLENNIUM PARK, BUDAPEST, HUNGARY

ARCHITECT - GÁBOR ZOBOKI dance theatre in the heart of Buda seems to be the most logical step to take considering the movement away from heavy industry towards cultural entertainment and associated activities. Easily accessed by private vehicles and public transport networks this former "temple of industry" provides the perfect space for a theatre. The new function, like dance is dynamic in form with timber stairs leading towards the main performance space. The puritan use of steelwork respects the building's industrial past whilst the fine detailed timber additions look to the future. THE LYRIC THEATRE COMPLEX, HONG KONG

Transformation of a former industrial building, later cultural centre, into a national

\section{EAST: FC BATE STADIUM, BORISZOV, BELARUS}

This UEFA four star accredited stadium establishes a different approach to the conventional expectations of a sports venue. Located in the centre of a densely forested site this building is both organic in form and function. Once inside all the visitors and players energy is directed towards, sport, training and entertainment without loss of contact to nature.

\section{YAMAMOTO, Asako: EUROPEAN ARCHITECTURE, JAPANESE DAYLIGHT} Citation: Metszet, Vol 10, No 1 (2019), pp 42-45, DOI: 10.33268/Met.2019.1.6 TWO WORKS BY ALPHAVILLE, JAPAN

A variation on the well known Japanese theme of building capsule hotels, constructed from regular sectioned timber columns and rafters placed at fixed intervals between which various functions are located: sleeping, bathrooms, eating and relaxation. Natural daylight being allowed to access the building along its central axis. NISHIOJI CITY HALL, KYOTO, JAPAN

Somewhat similar to the project in Koya this building is constructed from a regulated structural system: here instead of using timber sections concrete panels are to be used. Regimenting the use of space and eventual function. The building form is intentionally small in scale, although five stories high, in order to create a direct relationship to the timber framed "Machiya" or "Artisans" timber framed homes found in this part of Kyoto.

\section{ISHIGAMI, Junya: DREAMSCAPE} Citation: Metszet, Vol 10, No 1 (2019), pp 46-49, DOI: 10.33268/Met.2019.1.7 ART BIO FARM PROJECT, TOCHIGI, JAPAN

Convention has seen garden allotments being let to people in order to produce the maximum amount of crops in a small area. The concept behind this project is to allow people a chance to rent space which might be recreational as a driving priority. This dreamlike landscape will inspire creativity and therefore productivity by means of freedom of expression. Those who farm this land and its visitors alike can wander around flowing paths, easily access water sources and come to better understand he connection between the process of growing, harvesting, cooking and eventually sating.

\section{JÉRY, Attila: MOORISH ARCHITECTURE IN PEST}

\section{Titation: Metszet, Vol 10, No 1 (2019), pp 50-55, DOI: 10.33268/Met.2019.1.8} ARIS COURTYARD, BUDAPEST, HUNGARY

\section{ARCHITECTS - ARCHIKON}

Being faced with the challenge of restoring a monumental building in any major city Iways presents numerous problems, here this was added to by the presence of techical design faults, relating to the poor quality of later additions and repairs. Also questions of how to replace or repair decorative elements including the Zsolnay roof iles and ornaments. In addition to these challenges also fell the task of designing :ontemporary spaces and architectural additions, especially at roof level.

\section{SEBES, Péter: VILLA FOR SECULAR RETREAT, NEAR MEGALITHS}

\section{VIDECNIK, SPeIa: OFIS ARHITEKTIWEST ANDEAS Citation: Metszet, Vol 10, No 1 (2019), pp 38-41, DOI: 10.33268/Met.2019.1.5}

\section{WEST: BASKET APARTMENTS, PARIS, FRANCE}

A playful response was required for this development of short-term, student, housing on a site that measures $200 \times 11$ metres. Although the building core adheres to the linear demands of its given location architectural character has been enhanced by the use of attached/suspended basket structures to provides access walkways and balconies. Aside from the playful nature of this s development it also looks to the future in terms of environmental impact by generating its own solar energy and harvesting rainwater. Education can be fun, socially responsive and practical. Citation: Metszet, Vol 10, NNo 1 (2019), pp 56-59, DOI: 10.33268/Met.2019.1.9 VILLA, DEVON, UNITED KINGDOM

ARCHITECT - PETER ZUMTHOR

Secular living has lead towards the development of a temple for atheism. To be without belief, supposedly requires a timelessness expressed in monolith concrete forms where solid forms and the spaces between are expressed as opposites. The architect strives for an individual statement which does not conform to a particular style or language, therefore original. This building might be without the need for religious belief but it is still secular in its self. 